\title{
Erratum to: Biasing Effect on Modifying of the Tokamak Plasma Horizontal Displacement
}

\author{
Ahmad Salar Elahi • M. Ghoranneviss • \\ M. Tajdidzadeh · S. Mohammadi • Reza Arvin
}

Published online: 18 July 2010

(C) Springer Science+Business Media, LLC 2010

\section{Erratum to: J Fusion Energ \\ DOI 10.1007/s10894-010-9305-z}

The original version of this article unfortunately contained a mistake. The affiliations were incorrect. The corrected affiliations are given below.

[1] A. Salar Elahi, [2] M. Ghoranneviss, [2] M. Tajdidzadeh, [2] S. Mohammadi, [3] Reza Arvin.
1. Physics Department, Faculty of Engineering, Islamic Azad University, Saveh Branch, Saveh, Iran.

2. Plasma Physics Research Center, Science and Research Branch, Islamic Azad University, P.O. Box 14665-678, Tehran, Iran.

3. Faculty of Science, Central Tehran Branch, Islamic Azad University, Tehran, Iran.

The online version of the original article can be found under doi:10.1007/s10894-010-9305-z.

A. Salar Elahi $(\bowtie)$

Physics Department, Faculty of Engineering,

Islamic Azad University, Saveh Branch, Saveh, Iran

e-mail: salari_phy@yahoo.com

M. Ghoranneviss · M. Tajdidzadeh $\cdot$ S. Mohammadi

Plasma Physics Research Center, Science and Research Branch,

Islamic Azad University, P.O. Box 14665-678, Tehran, Iran

R. Arvin

Faculty of Science, Central Tehran Branch,

Islamic Azad University, Tehran, Iran 